\title{
Expression of Phosphoenolpyruvate Carboxykinase Isoforms in The Mam- mary Gland of Dairy Goats is Regulated by Insulin Status
}

\author{
Sameer J. Mabjeesh ${ }^{1, *}$, Nurit Argov-Argman ${ }^{1}$, Chris Sabastian ${ }^{1}$, Terresia Mbogori ${ }^{1}$ and Avi Shamay ${ }^{2}$ \\ ${ }^{I}$ Animal Science Department, The Robert H. Smith Faculty of Agriculture, Food and Environment, The Hebrew Univer- \\ sity of Jerusalem, Israel \\ ${ }^{2}$ Animal Science Department, The Volcani Center, Agricultural Research Organization, Israel
}

\begin{abstract}
Phosphoenolpyruvate carboxykinase (PEPCK) isoforms (c, cytosolic; m, mitochondria) are expressed in the liver and mammary gland. PEPCK-c is a rate-controlling enzyme for gluconeogenesis and glyceroneogenesis; its activity is decreased by insulin. PEPCK-m expression is constitutive and functions to channel lactate toward gluconeogenesis. We hypothesized that the increase in milk protein but decrease in milk lactose and fat when a hyperinsulinemic-euglycemic clamp (HIEC) is applied to dairy goats is due to decreased expression of mammary PEPCK-c mRNA. Late lactation goats $(\mathrm{n}=4 ; 150 \pm 30$ days in milk) were subjected to saline infusion and HIEC (104 $\mu \mathrm{g}$ insulin/h) for 4-day periods in a $2 \times 2$ crossover design. On day 4 of each period, a mammary biopsy $(\sim 1 \mathrm{~g})$ was taken from an udder half to determine expression of PEPCK-m and PEPCK-c mRNA by real-time RT-PCR. Plasma insulin increased 3.5-fold $(P<0.002)$ due to the HIEC and euglycemia was maintained. The HIEC decreased $(P<0.0001)$ dry matter intake $(28 \%)$ and milk yield $(26 \%)$. While milk fat content was not affected, HIEC increased $(P<0.001)$ milk protein content $(2.82 \%$ vs. $3.09 \%)$ but decreased $(P<0.001)$ milk lactose content $(4.22 \%$ vs. $4.03 \%)$. Expression of PEPCK-m mRNA was 9-fold higher $(P<0.004)$ than that of PEPCK-c. The HIEC decreased $(P<0.03)$ PEPCK-c mRNA 7-fold but tended to increase $(P<0.236)$ PEPCK-m mRNA 1.3-fold. These results demonstrate that insulin regulates mRNA expression of mammary PEPCK isoforms, and this may underlie the changes in milk-component synthesis observed when a HIEC is applied.
\end{abstract}

Keywords: Insulin, PEPCK, Mammary gland, goat.

\section{INTRODUCTION}

Insulin is considered an anabolic hormone that increases milk protein synthesis and secretion in dairy cows [1,2]. This effect occurs via orchestrated endocrine stimulation involving the IGF-1 axis and repartitioning of amino acids (AA) toward the mammary gland to favor milk protein synthesis $[3,4]$. Hence, the chronic (4 to 5 day) hyperinsulinemic-euglycemic clamp (HIEC) technique has been successfully used in dairy cows and goats to establish a responsive metabolic model for the study of anabolic effects of insulin. It has been shown that mammary blood flow and AA uptake are increased to support increased milk production and protein secretion during HIEC [4-6]. In an accompanying study, [4] demonstrated that HIEC in dairy goats also upregulates blood flow and AA-uptake processes across the hind-leg tissues. This suggests that the insulin clamp alters wholebody protein metabolism to enhance the supply of AA to all productive tissues, and not specifically the mammary gland. Interestingly, use of a HIEC for prolonged periods caused a dramatic improvement in milk protein production, up to $28 \%$ and $21 \%$, respectively, in response to abomasal supply of

*Address correspondence to this author at the Animal Science Department, The Robert H. Smith Faculty of Agriculture, Food and Environment, The Hebrew University of Jerusalem, Israel; Tel: 972-8-9489314;

Fax: 972-8-9489879; E-mail: sameer.mabjeesh@mail.huji.ac.il casein in dairy cows [3] or AA infusion into the circulation [5]. This led to the conclusion that in order to reach the raised set point of milk and protein production caused by endocrine stimulation, nutrients for at least the essential AA (EAA) must be supplied in adequate amounts to meet the metabolic demands for synthesis. What remains to be determined is how the HIEC affects and alters the use of EAA in productive tissues, e.g. protein synthesis and degradation vs. catabolism, at the tissue level, beyond blood supply and uptake. Another question is how the high energetic demands for these anabolic processes are met, supplied or repartitioned between tissues and within the metabolic pathways at the cell level.

The net removal of some EAA (Lys, Leu, Thr, Val, Ileu and Arg) by the cow, ewe and goat mammary gland is well known to be far in excess of milk protein synthesis requirements, whereas the removal of non-essential (NE) AA (Glu, Gln, Pro, Ala and Ser) is considerably less by 40 to $100 \%$ than requirements [7]. As a consequence, this latter group of AA must be synthesized de novo by the mammary gland. For example, the branched-chain AA are used to form intermediates of the glycolytic and TCA-cycle pathways and contribute to the pool of NEAA $[2,8,9]$. Moreover, the mammary gland synthesizes and secretes lactose and fat into milk from precursors taken up from the circulation [3]. The latter are composed of triglycerides containing short-, medium-, and long-chain fatty acids (FA) [10]. The long-chain FA (>C18) 
in milk are derived from preformed FA, whereas the shortand medium-chain FA are synthesized de novo from mainly acetate and, to a lesser extent, $\beta$-hydroxybutyrate [10]. Glucose is taken up from the circulation and is believed to be the main precursor for lactose synthesis in milk [11] calculated, on a net-balance basis, a ratio of 1.45 between glucose uptake by the mammary gland and lactose output in the milk of dairy cows, which increased to 1.63 with duodenal glucose infusion ( $\sim 2 \mathrm{~kg} /$ day). In contrast, in humans, $80 \%$ of the lactose in secreted milk was calculated to originate from glucose in the fed state [12]. Part of the deficit $(20 \%)$ was calculated to be from sources other than glucose, e.g. glycerol, while the rest could be contributed from the carbon skeleton of EAA [13]. Moreover, lactose is the major osmoregulator for the mammary gland, water uptake and milk volume. However, glucose can be metabolized to glycerol and contribute to some AA within the mammary gland tissue [14]. Hence, the shift between the different intracellular pools of substrate seems to be controlled by hormonal substrate availability and enzymatic activity. One of the key candidate enzymes for involvement in channeling substrates between intracellular pools is phosphoenolpyruvate carboxykinase (PEPCK).

PEPCK is expressed in the liver and a number of tissues, including the mammary gland, and it is generally considered to be the rate-limiting enzyme of gluconeogenesis [15]. This enzyme is expressed in two isoforms, cytosolic (PEPCK-c) and mitochondrial (PEPCK-m). Both isoenzymes are expressed in the bovine mammary gland [16], as well as in those of several other species [15]. In adipose tissue, PEPCK-c has been shown to participate in the process of glyceroneogenesis, which generates 3-P-glycerol from pyruvate and its precursors and is also involved in cataplerosis [15]. Early work by [17] suggested that PEPCK activity in the mammary gland may participate in carbohydrate metabolism at the level of the TCA cycle, and that it could serve a role in the mammary gland in the synthesis of lactose from non-glucose precursors. Diet and hormones such as insulin, glucagon and glucocorticoids acutely regulate PEPCK-c gene transcription. Virtually nothing is known about the factors controlling the transcription of the gene for PEPCK-m, and not much more is known about its metabolic role [18].

Thus, based on the above, we hypothesized that for EAA to make a net contribution to NEAA (or lactose) synthesis, their catabolism is required for entry into the Krebs Cycle between $\alpha$-ketoglutarate and oxaloacetate-phosphoenolpyruvate. Moreover, to ensure their partitioning toward synthesis of these NEAA, and thus casein, the activity of PEPCK-m must be greater than that of PEPCK-c. We also assumed that the use of chronic HIEC would further regulate the expression of the PEPCK isoforms to redirect substrates to satisfy the metabolic load on the mammary gland tissue for milk and protein synthesis. To study our hypothesis, we used 4-day HIEC on dairy goats, which has been shown to increase milk and milk protein production $[4,5]$. Milk fat and metabolism are discussed elsewhere [19].

\section{MATERIALS AND METHODS}

\section{Goats}

All procedures were approved by the Hebrew University Institutional Animal Care and Use Committee (permit num- ber AG-08-11414-3). Four lactating Saanen goats were used for the study. At the start of the experiment, the goats' BW averaged $51 \pm 7.5 \mathrm{~kg}$ and they were $100 \pm 15$ DIM. They were fed ad libitum ( $\pm 10 \%$ refusals of the daily meal) a ration composed of (70:30, on DM basis) a commercial pelleted dairy concentrate (mix \#16400, Ambar Feed Mill, Granot, Israel) and a roughage TMR (Newmix, International Feeding Center, Massout Itshak, Israel; Table 1). Throughout the experiment and between infusion periods, the ration was delivered by automatic feeders (12 equal meals at 2-h intervals). Goats were allowed to exercise twice daily for $1 \mathrm{~h}$ after milking.

\section{Experimental Design}

Goats were assigned to insulin clamp treatment according to a balanced $(2 \times 2)$ crossover design. The experiment consisted of two periods (separated by 2 wk) of continuous 4-d intravenous infusions of either saline $(240 \mathrm{~g} / \mathrm{d}, \mathrm{pH}$ 7.4) or insulin. One week before the start of each infusion period, goats were placed in metabolic cages for acclimatization. Between infusion periods, animals were kept in floor pens and fed by automatic feeders.

For the first $4 \mathrm{~d}$ of each period, venous blood was sampled by venopuncture into heparinized tubes daily at 0800 and $2000 \mathrm{~h}$. One portion of these samples was analyzed for plasma glucose with a hand-held glucose meter (ACCUCHECK, Sensor Comfort, Roche Ltd., Basel, Switzerland) to provide target glycemia levels for each goat during the insulin clamp. The rest of the samples were centrifuged at $2000 \times$ $g$ at $4^{\circ} \mathrm{C}$ for $15 \mathrm{~min}$ to harvest plasma, which was stored at $20^{\circ} \mathrm{C}$ for further analysis.

One day prior to the infusion, catheters (Delta $\mathrm{Ven}^{\circledR} 2$, G14Ø2.0×45mm Delta Med, s.r.I. 46019, Viadana, Italy) were inserted into both jugular veins. One catheter was used for infusion and the other for blood withdrawal. In case a catheter was not potent, saphenous or cephalic veins were used as an alternative.

The insulin solutions for infusion were prepared daily for each goat from frozen aliquots $(1 \mathrm{mg}$ insulin per $\mathrm{mL}$ sterile water containing $1 \% \mathrm{wt} / \mathrm{vol} \mathrm{BSA}$ and $50 \mu \mathrm{L} 6 \mathrm{~N} \mathrm{HCl}$ to dissolve the insulin) of bovine insulin (I-5500, Sigma Aldrich Co., St. Louis, MO). Aliquots $(2.88 \mathrm{~mL})$ were thawed and brought to $240 \mathrm{~mL}$ with sterile saline containing $0.1 \%$ BSA. The insulin solution was infused $(10 \mathrm{~mL} / \mathrm{h})$ i.v. through a sterile filter $(0.45 \mu \mathrm{m})$ to deliver $120 \mu \mathrm{g}$ insulin/h. During the insulin clamp, euglycemia was maintained by infusion of a glucose solution $(50 \% \mathrm{wt} / \mathrm{vol}$ dextrose monohydrate solution; Medical Teva, Pitach Tikva, Israel) at various rates. Within $15 \mathrm{~min}$, blood glucose was determined with the handheld glucose meter, and the glucose infusion rate was adjusted as needed. At the outset, blood sampling was frequent (20 to $30 \mathrm{~min}$ ) until euglycemia and glucose infusion rates became more stable; subsequently, blood samples were taken every 4 to $6 \mathrm{~h}$. Machine milking was performed at 0700 and $1900 \mathrm{~h}$, and milk yield was recorded by weight at each milking. One subsample was taken from the morning and following evening's milking and composited (1:1) into containers that included bronopol (2-bromo-2-nitropropane-1,3-diol and 2-bromo-2-nitropropanol) for analysis of fat, protein, and lactose with an infrared milk analyzer (Central Milk Lab, Caesaria, Israel). 
Table 1. Composition of the Experimental Diet

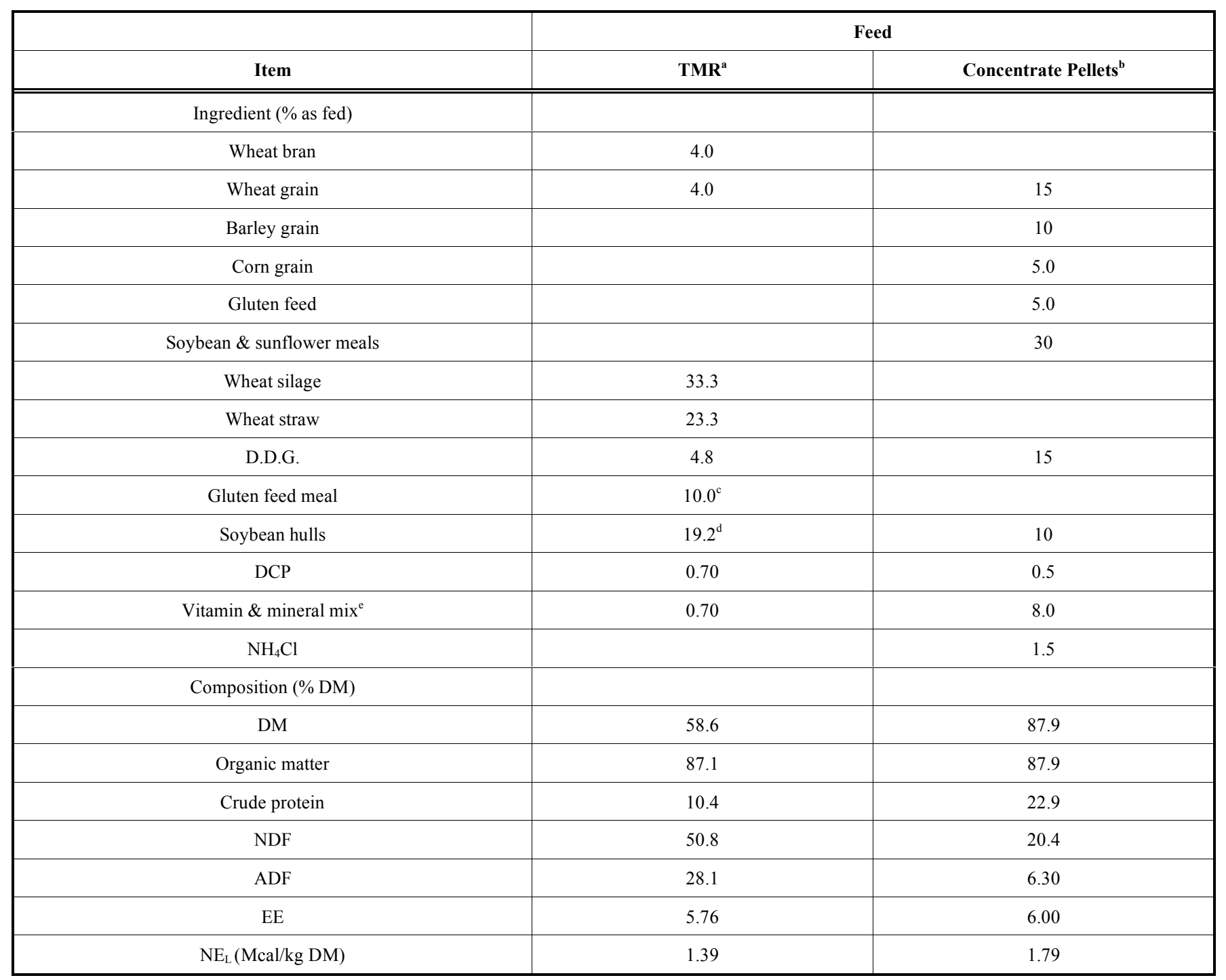

${ }^{\mathrm{a}}$ Newmix, International Feeding Center, Massout Itshak, Israel.

${ }^{b}$ Mixture 16400®, Ambar Feed Mill, Granot, Israel.

${ }^{\mathrm{c}}$ Wet.

${ }^{\mathrm{d}}$ Molassed.

${ }^{\mathrm{e}}$ Contained, per kg: 20,000,000 IU vitamin A, 2,000,000 IU vitamin D, 15,000 mg vitamin E; 6000 ppm Mn, 6000 ppm Zn, 2000 ppm Fe, 1500 ppm Cu, 120 ppm I, 50 ppm Se, and 20 ppm Co.

At the end of the $96 \mathrm{~h}$ clamp, mammary tissue biopsies were taken under general anesthesia. After proper preparation of the skin area on the upper part of the gland, an incision of $2 \mathrm{~cm}$ was made in the skin and subdermis. The fascia, fat tissue and connective tissue were removed by sharp dissection until the mammary gland tissue was visible. Approximately $2 \mathrm{~g}$ of tissue was taken, rinsed in $0.9 \%$ sterile saline solution, inspected to verify tissue homogeneity and divided into two equal portions: one was snap-frozen in liquid nitrogen and the other was placed in RNAlater solution (Applied Biosystems, Ambion, Foster City, CA). Frozen samples were then stored at $-80^{\circ} \mathrm{C}$ and the others were stored at $4^{\circ} \mathrm{C}$.

\section{Analysis of Plasma Insulin Concentration}

Plasma insulin was determined by radioimmunoassay using the DSL-1600 insulin radioimmunoassay kit (Diagnos- tic Systems Laboratories, Webster, TX) according to the manufacturer's instructions.

\section{RNA Extraction and Analysis}

Total RNA was isolated from mammary gland tissues by the acid guanidiniumthiocyanate phenol-chloroform extraction method [20]. Briefly, tissues were harvested in Trireagent (MRC Inc., Cincinnati, $\mathrm{OH}$ ) according to the manufacturer's protocol. Amount and quality of RNA were determined by Nanodrop spectrophotometry (NanoDrop Technologies, Wilmington, DE). The RNA was kept at $-80^{\circ} \mathrm{C}$ until further analysis.

\section{Reverse Transcription (RT)}

RNA samples were treated with DNAse solution (Ambicon Inc., Austin, TX) following the manufacturer's instructions. Then RNA was reverse-transcribed according to ABgene UK's instructions in a final volume of $20 \mu \mathrm{L}$. First, $1 \mu \mathrm{g}$ 
(A)

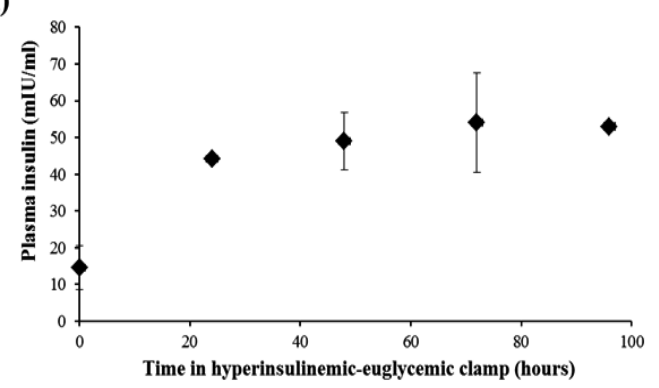

(B)

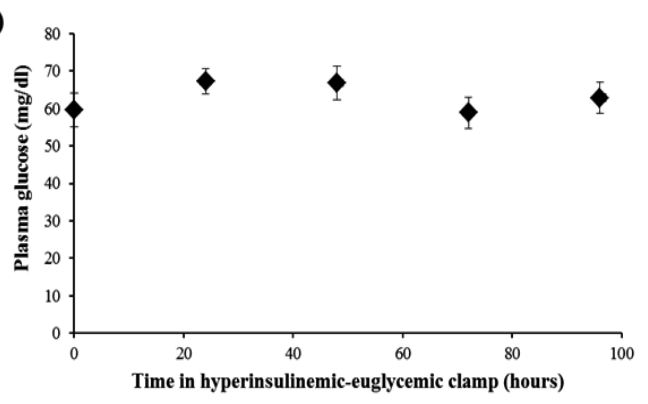

(C)

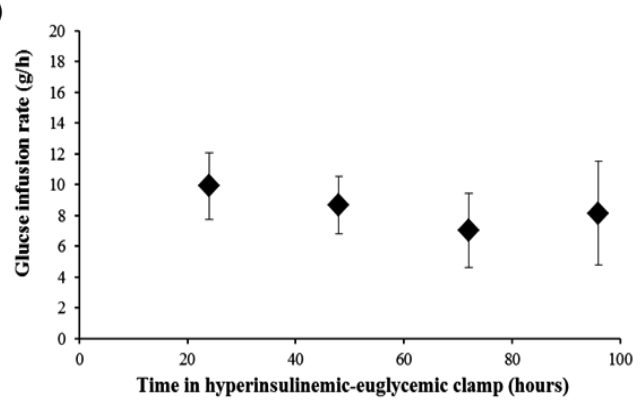

Fig. (1). (A) Plasma insulin concentration $(\mathrm{mIU} / \mathrm{mL})$ and (B) plasma glucose concentration $(\mathrm{mg} / \mathrm{dL})$ in lactating goats subjected to 4 days HIEC. (C) Glucose infusion rate $(\mathrm{g} / \mathrm{h})$ needed to maintain euglycemia. Data are averages of multiple sampling points during the clamp. Averages $(n=4)$ are presented as LS means \pm SE.

RNA with anchored oligo-dT primers (500 ng) and random hexamers $(1200 \mathrm{ng})$ at a ratio of $1: 3$, total volume of $12 \mu \mathrm{L}$, was heated at $70^{\circ} \mathrm{C}$ for $5 \mathrm{~min}$. Then $4 \mu \mathrm{L}$ of cDNA synthesis buffer (5X), $1 \mu \mathrm{L}$ Verso enzyme, $2 \mu \mathrm{L}$ dNTP mix and $1 \mu \mathrm{L}$ RT enhancer were added to a final volume of $20 \mu \mathrm{L}$. The reaction was run for $1 \mathrm{~h}$ at $47^{\circ} \mathrm{C}$ and the enzyme was stopped by heating to $95^{\circ} \mathrm{C}$ for $2 \mathrm{~min}$. The product (cDNA) was kept at $-20^{\circ} \mathrm{C}$.

\section{Real-Time (rt) PCR}

The reverse-transcribed RNA samples were analyzed by rt-PCR with the StepOnePlus Real-Time PCR System (Applied Biosystems). The reaction was carried out in a final volume of $10 \mu \mathrm{L}: 5 \mu \mathrm{L}$ SYBR Green mix (ABgene UK), 0.5 $\mu \mathrm{L}$ of $5 \mu \mathrm{M}$ forward primer, $0.5 \mu \mathrm{L}$ of $5 \mu \mathrm{M}$ reverse primer and $4 \mu \mathrm{L}$ template ( 0.5 to $10 \mathrm{ng} / \mu \mathrm{L} \mathrm{cDNA})$. After enzyme activation at $95^{\circ} \mathrm{C}$ for $15 \mathrm{~min}, 40$ cycles were run of $1 \mathrm{~min}$ denaturation at $95^{\circ} \mathrm{C}, 2 \mathrm{~min}$ annealing at $60^{\circ} \mathrm{C}$, and $1 \mathrm{~min}$ extension at $72^{\circ} \mathrm{C}$. The amplified PCR product was analyzed with the StepOne Real-Time PCR System. At the end of the rt-PCR run, a melting curve was determined to verify the presence of a single amplicon. For each gene, a standard curve was generated to determine reaction efficacy. The primers used were as follows $\left(5^{\prime} \rightarrow 3^{\prime}\right)$ :

\section{S (F): CAGAAACAAAATTATTCGCCAGAGT \\ 16S (R): GGGTATAAAGCACCGCCAAGT \\ PEPCK-c (F): CAACTACTCAGCCAAAATCG \\ PEPCK-c (R): ATCGCAGATGTGGACTTG \\ PEPCK-m (F): GCTACAACTTTGGGCGCTAC \\ PEPCK-m (R): GTCGGCAGATCCAGTCTAGC}

The rt-PCR analysis was performed with StepOne software v2.1 (Applied Biosystems). The proportional change in mRNA was shown as fold change, i.e. the change between mRNA expression with treatment and without (control). Efficacy of amplification was calculated from the standard curve of each gene.

\section{Statistical Analysis}

All statistical analyses for DMI, milk and milk component yields, and plasma insulin were performed using JMP software version 7 (SAS Institute, Cary, NC). Treatment, goat and period were used as model effects. The results for gene expression were tested by Student's $t$ test. All dependent variables were checked for normality by goodness of fit application of the distribution analysis and unequal variances of JMP. All reported data are least squares means. Significance was set at $P<0.05$.

\section{RESULTS}

\section{Insulin Clamp}

Plasma insulin was elevated 3.5 -fold $(P<0.002)$ during the clamp, whereas plasma glucose remained at baseline levels (Fig. 1A and Table 2). To obtain this baseline glucose level, dextrose solution was infused during the clamp at an average $8.44 \pm 2.45 \mathrm{~g} / \mathrm{h}$ (Fig. 1B and C). The infusion rate of dextrose differed largely between goats and time of day depending on requirements to maintain euglycemia.

\section{Goats' Performances}

Feed intake (kg DM/day) during the insulin clamp period decreased dramatically (by $28 \%$, Table 2 ) compared to the control period. When daily dry matter intake (DMI) was expressed per metabolic BW, goats consumed $147 \mathrm{~g} / \mathrm{kg} \mathrm{BW}^{0.75}$ in the control period compared to $109 \mathrm{~g} / \mathrm{kg} \mathrm{BW}^{0.75}$ in the insulin clamp period; a $26 \%$ reduction $(P<0.0001)$. Similarly, milk yield decreased significantly (by $21 \%$, Table 2 ) during the insulin clamp period (Table 2). Milk fat and lactose yields decreased by $15 \%$ and $24 \%$, respectively, whereas milk protein yields tended to decrease (Table 2). Milk fat percentage was similar between periods $(P<0.115)$, whereas protein percentage increased significantly ( $3.27 \mathrm{vs}$. $3.71 ; P<0.0001)$ during the clamp. However, lactose percentage decreased significantly from 4.22 to 4.03 during the insulin clamp $(P<0.0001)$.

\section{Mammary Gland PEPCK Expression}

The expression of PEPCK mRNA in the mammary gland of dairy goats is presented in Fig. (2A) and (2B). The expression of PEPCK-m was $\sim 9$-fold higher $(P<0.004)$ than 
Table 2. Feed Intake, Milk Yield and Composition, Plasma Glucose and Insulin Concentrations of Goats During Control and 4-day Hyperinsulinemic-Euglycemic Clamp

\begin{tabular}{|c|c|c|c|c|}
\hline Item & Control $^{\mathrm{a}}$ & Treatment $^{\mathrm{b}}$ & RMSE & $P<$ \\
\hline Feed intake $\left(\mathrm{g} / \mathrm{kg} \mathrm{BW}^{0.75}\right.$ per day) & 117.4 & 84.4 & 16.7 & 0.0001 \\
\hline Milk yield (kg/day) & 2.21 & 1.75 & 0.36 & 0.003 \\
\hline \multicolumn{5}{|l|}{ Milk composition (\%) } \\
\hline Protein & 3.27 & 3.71 & 0.22 & 0.0001 \\
\hline Lactose & 4.22 & 4.03 & 0.09 & 0.0001 \\
\hline \multicolumn{5}{|l|}{ Milk components, yield (g/day) } \\
\hline Fat & 60.8 & 51.5 & 11.1 & 0.039 \\
\hline Plasma insulin $(\mu \mathrm{IU} / \mathrm{mL})$ & 14.6 & 51.4 & 26.5 & 0.002 \\
\hline
\end{tabular}

${ }^{\mathrm{a} C}$ Control involved continuous i.v. infusions of saline (240 g/day, $\left.\mathrm{pH} 7.4\right)$.

${ }^{\mathrm{b}}$ Treatment involved i.v. infusion of insulin $(10 \mathrm{~mL} / \mathrm{h})$ through a sterile filter $(0.45$ micron $)$ to deliver $120 \mu \mathrm{g}$ insulin $/ \mathrm{h}$.

that of PEPCK-c. During the HIEC, the expression of PEPCK-c was dramatically decreased $(P<0.03)$ by 7 -fold compared to the saline infusion, while that of PEPCK-m was only numerically increased (by 1.3 -fold, $P<0.236$ ).

\section{DISCUSSIN}

Lactating goats were subjected to HIEC to study the effect of insulin on milk synthesis and expression of PEPCK isoenzymes. Previous studies in lactating goats utilized HIEC to study the effect of insulin on milk protein synthesis and secretion in the mammary glands [5]. In the current study, plasma insulin concentration was successfully elevated 3.5-fold and blood glucose was maintained at $63.2 \pm$ $1.03 \mathrm{mg} / \mathrm{dL}$ throughout the experimental period.

Feed intake during the insulin clamp period was reduced dramatically compared to controls, similar to that observed previously in dairy cows [3,21,22], but differing from other studies [2, 4, 23] where insulin had no effect on DMI. The latter studies offered either sufficient net energy for lactation $\left(\mathrm{NE}_{\mathrm{L}}\right)$ or surplus energy in the diet to meet requirements. Attempts to find a relationship between energy consumption and energy status i.e. days in milk (DIM) of the tested animals did not reveal any consistency with respect to feed intake. The reduction in feed intake during the insulin clamp might occur as a systemic or direct endocrine effect in the central nervous system (CNS). Insulin has been shown to act directly as a regulator of energy homeostasis in the CNS, either alone or together with leptin, while a high concentration of either hormone depressed food intake in a rodent model [24]. The reduction in DMI in the current study did not result in negative energy balance during the clamp. Considering the glucose infused during the HIEC, goats in the current study received on average $203 \mathrm{~g}$ glucose daily to maintain euglycemia, which is equal to $0.87 \mathrm{Mcal}$ of metabolizable energy (ME) assuming $4.3 \mathrm{Mcal}$ of $\mathrm{ME} / \mathrm{kg}$ glu- cose [25]. Calculating the energy intake, and requirements for maintenance and milk production using the National Research Council model [26], the goats during the clamp were at $\sim 100 \%$ balance in accordance to their milk production. However, they were still at a shortage of $\sim 26 \%$ of ME/day compared to the control treatment in terms of milk production. Hence, it can be concluded that milk production was reduced as a consequence of ME shortage during the clamp.

Milk yield decreased by $26 \%$ during the insulin clamp period compared with controls. These results differ from those observed in other insulin clamp studies where milk yield was either increased [2,4] or not affected [1, 3, 23]. These contradictory results might be due to the experimental design or the species used. In [4], the authors used a ration for dairy goats that was calculated to provide $95 \%$ of ME and $143 \%$ of metabolizable protein (MP) in a factorial design with or without i.v. infusion of AA during the clamp. The same was done in the dairy cow experiment [2], in which diets were formulated to exceed requirements for ME and MP to support production in a similar arrangement, but casein and branched-chain AA were infused through the abomasum. Neither study detected any reduction in DMI. However, in the experiment reported by McGuire et al. [3], the total mixed ration (TMR) was designed to provide $120 \%$ of requirements and feed intake was decreased by $41 \%$ during the clamp, with no change in milk production. The increase in milk production during the HIEC is thought to be mediated through the insulin like growth factor IGF system, blood flow, and metabolic regulation at the organ level [4]. What appears to be consistent throughout these studies is that diets were designed to exceed requirements in a manner that did not affect precursor availability for milk production, whereas infusion of either AA or casein supported milk production demands when production was increased. In the current study, the TMR was designed to support $\sim 110 \% \mathrm{MP}$ and 
(A)

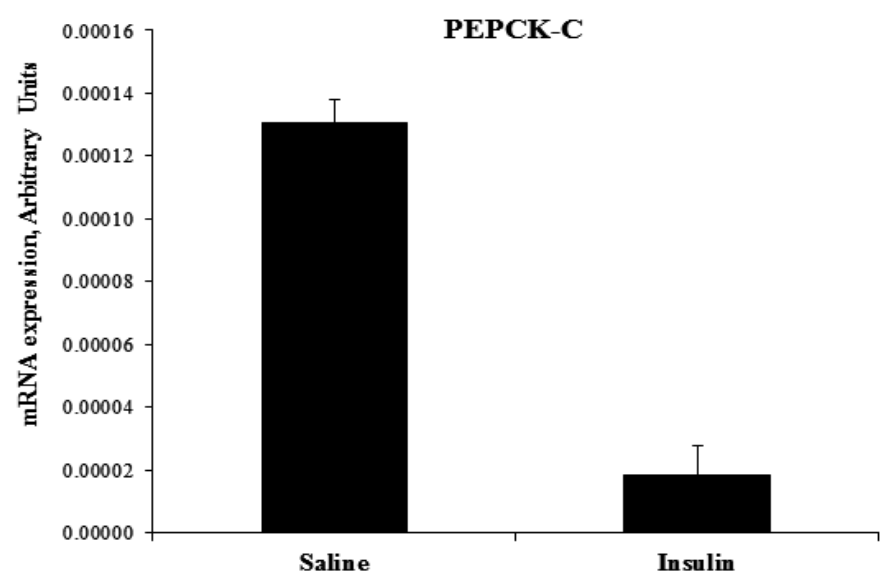

(B)

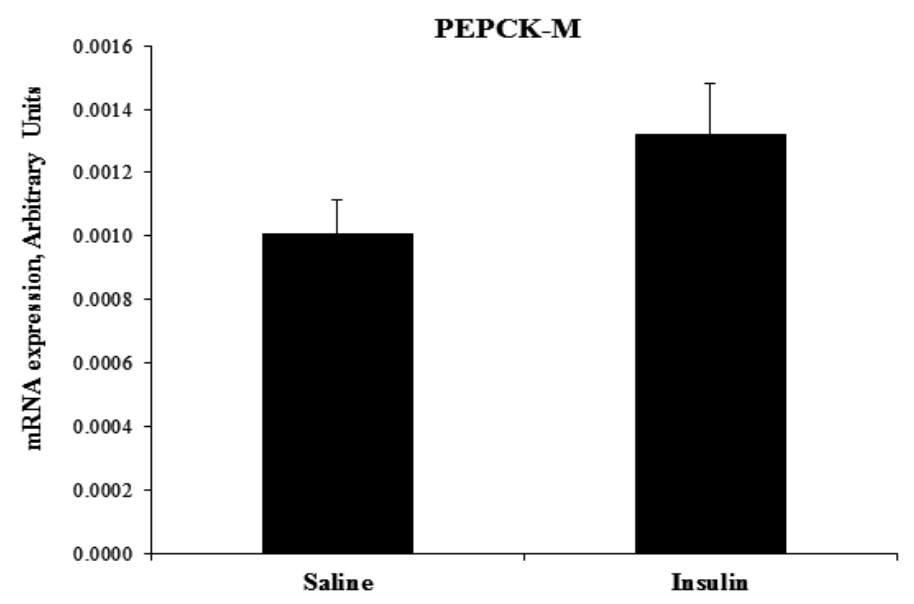

Fig. (2). Effect of HIEC on mRNA expression of (A) PEPCK-c and (B) PEPCK-m in the mammary gland tissue of lactating goats. Insulin infusion decreased $(P<0.03)$ the PEPCK-c expression 7-fold while it numerically $(P<0.236)$ increased the expression of PEPCK-m 1.3fold. Overall expression of PEPCK-m was $\sim 9$-fold higher $(P<0.004)$ than that of PEPCK-c in the mammary gland.

$\sim 113 \%$ ME of the calculated requirements [26]. Hence, when feed intake was decreased by $26 \%$, the MP supply would be decreased by at least this proportion and most probably to a larger extent, because microbial protein flow relies on fermentable energy as well [26]. Based on the above, insulin during HIEC increased milk and milk protein production when energy and AA were available either from feed intake or exogenously.

Interestingly, a significant increase in milk protein concentration was observed in the current study: despite the fact that milk yield was decreased by $26 \%$, milk protein yield tended to decrease $(P<0.07)$ by only $10 \mathrm{~g} /$ day during the HIEC. When HIEC was applied to dairy cows, the partition of AA to the mammary gland was considerably enhanced and milk protein synthesis and secretion increased [1-3]. Bequette et al. (2001) measured an increase in milk protein synthesis when HIEC with or without i.v. infusion of AA was applied to dairy goats. Further, those authors demonstrated that blood flow and tissue-transport activity of several EAA also increase. It can be concluded that the
EAA also increase. It can be concluded that the increase in milk protein concentration in the current study was a consequence of higher protein synthesis in the udder that was triggered by insulin, higher EAA utilization and repartitioning of precursors at the intercellular level.

To further address the mechanism by which the gland utilizes and repartitions EAA to different metabolic pathways for protein synthesis, we measured the expression of the PEPCK isoenzymes in the mammary gland at the end of each experimental period. This enzyme is highly expressed and considered to be a key enzyme of gluconeogenesis in liver tissue, where it is adaptively regulated by a variety of different metabolic hormones (e.g. insulin) and other agents in a manner paralleling glucogenic turnover [27, 28]. Unlike the liver, in the mammary gland tissue the expression of PEPCK-m was $\sim 9$-fold higher than that of PEPCK-c [15]. This observation confirms our proposed assumption that to ensure partitioning of EAA toward synthesis of NEAA, and thus casein, the activity of PEPCK-m must be greater than 
that of PEPCK-c. We also assumed that the use of chronic HIEC would further regulate the expression PEPCK isoenzymes, in order to redirect substrates to satisfy the metabolic load on the mammary gland tissue for milk and protein synthesis. Indeed, during the HIEC, expression of PEPCK-c, which is highly affected and downregulated by insulin [15], decreased 7-fold compared to controls, whereas expression of the isoenzyme PEPCK-m was numerically increased 1.3fold during the clamp. This parallels the finding in the mammary gland of guinea pigs, where PEPCK-m activity was found to increase dramatically (43-fold) during the transition to lactation compared to the cytosolic isoform [29]. Those authors also observed that at mid-lactation, PEPCK-m constitutes $86 \%$ of the total gland PEPCK activity compared to $60 \%$ prepartum. Thus, the PEPCK-m isoform in the guinea pig mammary gland tissue appears to play the more important role in the conversion of oxaloacetate to PEP [29]. Interestingly, the opposite observation was made in the rat mammary gland [30]. Those researchers recorded a dramatic (40-fold) increase in activity for PEPCK-c at the onset of lactation and a rapid decrease (95\%) in activity when dams were separated from pups. These discrepancies may be related to differences in substrate requirements for milk and milk component synthesis and secretions and accordingly, the hormonal profile involved.

It is therefore concluded that increased protein synthesis in the mammary gland of goats under HIEC is altered via orchestrated metabolic pathways that include systemic changes in peripheral tissues' utilization of ME, repartitioning of EAA between productive tissues, rechanneling of substrates at the cellular level and changes in gene expression. The isoforms of the enzyme PEPCK in the mammary gland are one of the routes involved in this process.

\section{AUTHOR CONTRIBUTIONS}

Conceived and designed the experiments: SJM AS. Performed the experiments: SJM AS CS NAA TM. Analyzed the data: SJM TM AS CS. Contributed reagents/materials/analysis tools: NAA AS SJM. Wrote the paper: SJM NAA CS TM AS.

\section{CONFLICT OF INTEREST}

The authors confirm that this article content has no conflicts of interest.

\section{ACKNOWLEDGEMENTS}

Declared none.

\section{REFERENCES}

[1] Griinari JM, McGuire MA, Dwyer DA, Bauman DE, Barbano DM, House WA. The role of insulin in the regulation of milk protein synthesis in dairy cows. J Dairy Sci 1997; 80(10): 2361-71.

[2] Mackle TR, Dwyer DA, Ingvartsen KL, et al. Effects of insulin and amino acids on milk protein concentration and yield from dairy cows. J Dairy Sci 1999; 82(7): 1512-24.

[3] McGuire MA, Dwyer DA, Harrell RJ, Bauman DE. Insulin regulates circulating insulin-like growth factors and some of their binding proteins in lactating cows. Am J Physiol 1995; 269(4 Pt 1): E723-30.

[4] Bequette BJ, Kyle CE, Crompton LA, Buchan V, Hanigan MD. Insulin regulates milk production and mammary gland and hind-leg amino acid fluxes and blood flow in lactating goats. J Dairy Sci. 2001; 84(1): 241-55.
[5] Bequette BJ, Kyle CE, Crompton LA, Anderson SE, Hanigan MD. Protein metabolism in lactating goats subjected to the insulin clamp. J Dairy Sci 2002; 85(6): 1546-55.

[6] Mackle TR, Dwyer DA, Ingvartsen KL, Chouinard PY, Ross DA, Bauman DE. Effects of insulin and postruminal supply of protein on use of amino acids by the mammary gland for milk protein synthesis. J Dairy Sci 2000; 83(1): 93-105.

[7] Bequette BJ, Backwell FR, Crompton LA. Current concepts of amino acid and protein metabolism in the mammary gland of the lactating ruminant. J Dairy Sci 1998; 81(9): 2540-59.

[8] Clark JH, Spires HR, Davis CL. Uptake and metabolism of nitrogenous components by the lactacting mammary gland. Fed Proc 1978; 37(5): 1233-8.

[9] Mepham TB. Amino acid utilization by lactating mammary gland J Dairy Sci 1982; 65(2): 287-98.

[10] Bauman DE, Davis CL. Biosynthesis of milk fat. In: Larson BL and Smith VR, Eds. Lactation: A Comprehensive Treatise. $2^{\text {nd }}$ ed New York NY: Academic Press, 1974; p. 31.

[11] Rigout S, Lemosquet S, van Eys JE, Blum JW, Rulquin H. Duodenal glucose increases glucose fluxes and lactose synthesis in grass silage-fed dairy cows. J Dairy Sci 2002; 85(3): 595-606.

[12] Sunehag A, Tigas S, Haymond MW. Contribution of plasma galactose and glucose to milk lactose synthesis during galactose ingestion. J Clin Endocrinol Metab 2003; 88(1): 225-9.

[13] Bequette BJ, Owens SL, El-Kadi SW, Sunny NE, Shamay A. Use of 13C-mass isotope distribution analysis (MIDA) to define precursors for lactose and amino acid synthesis by bovine mammary explants. J Dairy Sci 2005; 88(Suppl. 1): 289.

[14] Katz J, Wals PA. Pentose cycle and reducing equivalents in rat mammary-gland slices. Biochem J 1972; 128(4): 879-99.

[15] Chakravarty K, Cassuto H, Reshef L, Hanson RW. Factors that control the tissue-specific transcription of the gene for phosphoenolpyruvate carboxykinase-C. Crit Rev Biochem Mol Biol. 2005; 40(3): 129-54.

[16] Agca C, Greenfield RB, Hartwell JR, Donkin SS. Cloning and characterization of bovine cytosolic and mitochondrial PEPCK during transition to lactation. Physiol Genomics 2002; 11(2): 53-63.

[17] Baird GD. Fructose-1,6-diphosphatase and phosphopyruvate carboxykinase in bovine lactating mammary gland. Biochim Biophys Acta 1969 1; 177(2): 343-5.

[18] Hanson RW, Patel YM. Phosphoenolpyruvate carboxykinase (GTP): the gene and the enzyme. Adv Enzymol Relat Areas Mol Biol. 1994; 69: 203-81.

[19] Argov-Argman N, Mbogori T, Sabastian C, Shamay A, Mabjeesh SJ. Hyperinsulinogenic euglycemic clamp modulates milk fat globule and its membrane lipid composition in goats. J Dairy Sci. 2012; 95: 5776-87.

[20] Chomczynski P, Sacchi N. Single-step method of RNA isolation by acid guanidinium thiocyanate-phenol-chloroform extraction. Anal Biochem 1987; 162(1): 156-9.

[21] Molento CF, Block E, Cue RI, Petitclerc D. Effects of insulin, recombinant bovine somatotropin, and their interaction on insulinlike growth factor-I secretion and milk protein production in dairy cows. J Dairy Sci 2002; 85(4): 738-47.

[22] Griinari JM, McGuire MA, Dwyer DA, Bauman DE, Palmquist DL. Role of insulin in the regulation of milk fat synthesis in dairy cows. J Dairy Sci 1997; 80(6): 1076-84.

[23] Corl BA, Butler ST, Butler WR, Bauman DE. Short communication: Regulation of milk fat yield and fatty acid composition by insulin. J Dairy Sci 2006; 89(11): 4172-5.

[24] Figlewicz DP, Benoit SC. Insulin, leptin, and food reward: update 2008. Am J Physiol Regul Integr Comp Physiol 2009; 296(1): R919.

[25] Armstrong DG, Blaxter KL. The utilization of energy of carbohydrte by ruminanats. In: Proc 2nd Symp Energy Metab Eur Assoc Anim Prod. Wagenningen, The Netherlands 1961; pp. 187-99.

[26] NRC. Nutrient Requirements of Small Ruminants: Sheep, Goats, Cervids, and New World Camelids. Washington, DC: National Academy Press, 2007.

[27] She P, Burgess SC, Shiota M, et al. Mechanisms by which liverspecific PEPCK knockout mice preserve euglycemia during starvation. Diabetes 2003; 52(7): 1649-54.

[28] Hanson RW, Reshef L. Regulation of phosphoenolpyruvate carboxykinase (GTP) gene expression. Annu Rev Biochem 1997; 66: 581-611. 
[29] Jones DH, Raymer DM, Schoelen SL. The activity of phosphoenolpyruvate carboxykinase throughout the lactation cycle of the guinea pig mammary gland. Proc Soc Exp Biol Med 1989; 192(1): $16-22$
[30] Garcia-Ruiz JP, Lobato MF, Ros M, Moreno FJ. Presence of cytosolic phosphoenolpyruvate carboxykinase activity in rat mammary gland. Enzyme 1983; 30(4): 265-8.

Received: March 20, 2013

Revised: June 30,2013

Accepted: July 30, 2013

(C) Mabjeesh et al.; Licensee Bentham Open.

This is an open access article licensed under the terms of the Creative Commons Attribution Non-Commercial License (http://creativecommons.org/licenses/by-nc/3.0/) which permits unrestricted, non-commercial use, distribution and reproduction in any medium, provided the work is properly cited. 